\title{
LEVELS OF PROGESTERONE, LH AND FSH IN THE PLASMA OF SHEEP DURING THE OESTROUS CYCLE
}

\author{
N. F. GUNNINGHAM, A. M. SYMONS* AND N. SABA \\ Ministry of Agriculture, Fisheries and Food, Central Veterinary Laboratory, \\ New Haw, Weybridge, Surrey KT15 3NB
}

(Received 15th February 1975)

Although the changes occurring in the plasma levels of progesterone and $\mathrm{LH}$ during the oestrous cycle of sheep have been well documented, there is some doubt about the pattern of plasma FSH concentrations. We present some data on the levels of all three hormones in a limited number of plasma samples taken from ewes experiencing normal oestrous cycles.

Eight 3-year-old Cheviot ewes were kept in a paddock with a vasectomized ram during October and November. The ram was fitted with a marking harness and the coloured crayon on the harness was changed every 15 days. The ewes were examined daily and the day that a ewe was first marked by the ram was designated Day 0 of the cycle. Blood samples were taken from the jugular vein into heparinized $10 \mathrm{ml}$ Vacutainers (Becton-Dickinson U.K. Ltd) and were centrifuged at $4^{\circ} \mathrm{C}$ within $1 \mathrm{hr}$. Plasma was stored at $-15^{\circ} \mathrm{C}$ until required for hormone assays. Blood samples were generally taken between 09.30 and 11.30 hours each day, but around the time of oestrus samples were taken at approximately 09.00 hours (Sample $a$ ), 12.00 hours (Sample $b$ ) and 15.30 hours (Sample $c$ ). The ewes had exhibited at least one oestrous cycle before blood samples were taken. Plasma progesterone levels were estimated by a modification (Symons, 1973) of the Dextran-coated charcoal radioimmunoassay for oestrogens described by Challis et al. (1971). Plasma FSH and LH were determined by the polystyrene tube radioimmunoassays previously described (Cunningham \& Hebert, 1973; Symons et al., 1974), using NIHFSH-S4 and NIH-LH-S17 as standards.

The cycle lengths of individual ewes ranged from 15 to 17 days. Plasma progesterone levels increased progressively during the period 15 to 9 days before oestrus to a mean level of about $2.5 \mathrm{ng} / \mathrm{ml}$, and remained at this level for several days (Text-fig. 1). By 2 days before oestrus, the mean plasma progesterone concentration had fallen to $1.42 \mathrm{ng} / \mathrm{ml}$, and on the following day it had dropped to $<0.5 \mathrm{ng} / \mathrm{ml}$. It remained at this low level until after Day 2 of the cycle, and then again showed a progressive rise. This pattern of changes in progesterone concentration during the oestrous cycle of sheep is similar to that found in peripheral plasma by other workers (Stabenfeldt et al., 1969; Thorburn et al., 1969) and reflects the activity of the corpus luteum.

* Present address: Department of Biochemistry, University of Surrey, Guildford, Surrey. 
Plasma LH and FSH levels for individual ewes during the oestrous cycle are shown in Text-fig. 2. Basal levels of the gonadotrophins were generally $<1 \mathrm{ng}$ $\mathrm{LH} / \mathrm{ml}$ and 20 to $60 \mathrm{ng} \mathrm{FSH} / \mathrm{ml}$. Three ewes showed well-defined gonadotrophin peaks on Day 0 (Nos 782 and 820) or Day - 1 (No. 814), peak LH (15 to $59 \mathrm{ng} / \mathrm{ml}$ ) and FSH ( 75 to $293 \mathrm{ng} / \mathrm{ml}$ ) concentrations occurring in the same samples. Two ewes showed small elevations of plasma LH (5 to $6 \mathrm{ng} / \mathrm{ml}$ ) on Day 0 (No. 784) and Day 1 (No. 822), but no elevation of plasma FSH (No. $784)$ or only a slight increase $(78 \mathrm{ng} / \mathrm{ml})(\mathrm{No} .822)$. The remaining three ewes (Nos 781, 783 and 815) showed no evidence of elevated LH or FSH levels in samples taken around the time of oestrus.

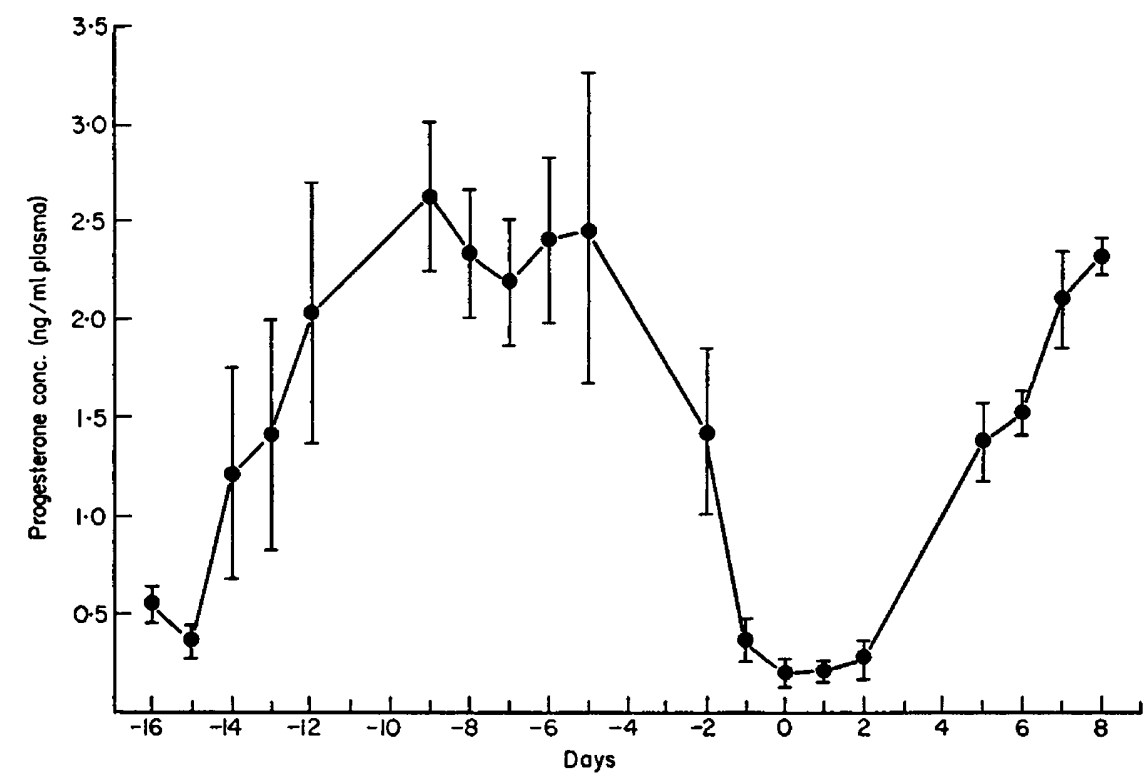

TEXT-Fig. 1. Plasma progesterone levels during the oestrous cycle of eight ewes. Each point represents the mean for three to eight animals and vertical bars indicate the S.E.M. Day $0=$ day of oestrus.

The pattern of the preovulatory LH surge in the peripheral blood of cyclic ewes has been studied by several groups of workers (see for example Niswender et al., 1968; Goding et al., 1969; Wheatley \& Radford, 1969; Kann, 1971). The LH levels usually started to rise 0 to $16 \mathrm{hr}$ after the onset of oestrus, and the duration of elevated LH levels was generally $<12 \mathrm{hr}$. In the present experiments, two ewes (Nos 782 and 820) showed such LH peaks on the day of oestrus, and two ewes (Nos 784 and 822) showed small elevations of plasma LH which might have represented the leading and trailing edges of an LH surge occurring during the $17 \frac{1}{2} \mathrm{hr}$ between Sample $c$ on Day 0 and Sample $a$ on Day 1. The marked LH surge observed in Ewe 814 on the day before oestrus is consistent with the findings of Lishman et al. (1974) that the LH peak occurred at or before the onset of overt oestrus in 22/92 oestrous periods studied. In view of the relatively short duration of the $\mathrm{LH}$ surge, our failure to detect elevated 
LH levels in three sheep around the time of oestrus was probably due to insufficient sampling at the critical times.

The occurrence of an FSH peak coincident with the LH surge in three sheep around the time of oestrus is in agreement with the observations of other workers (L'Hermite et al., 1972; Pant et al., 1973; Salamonsen et al., 1973) that FSH levels on the day of oestrus were elevated when LH levels were at their

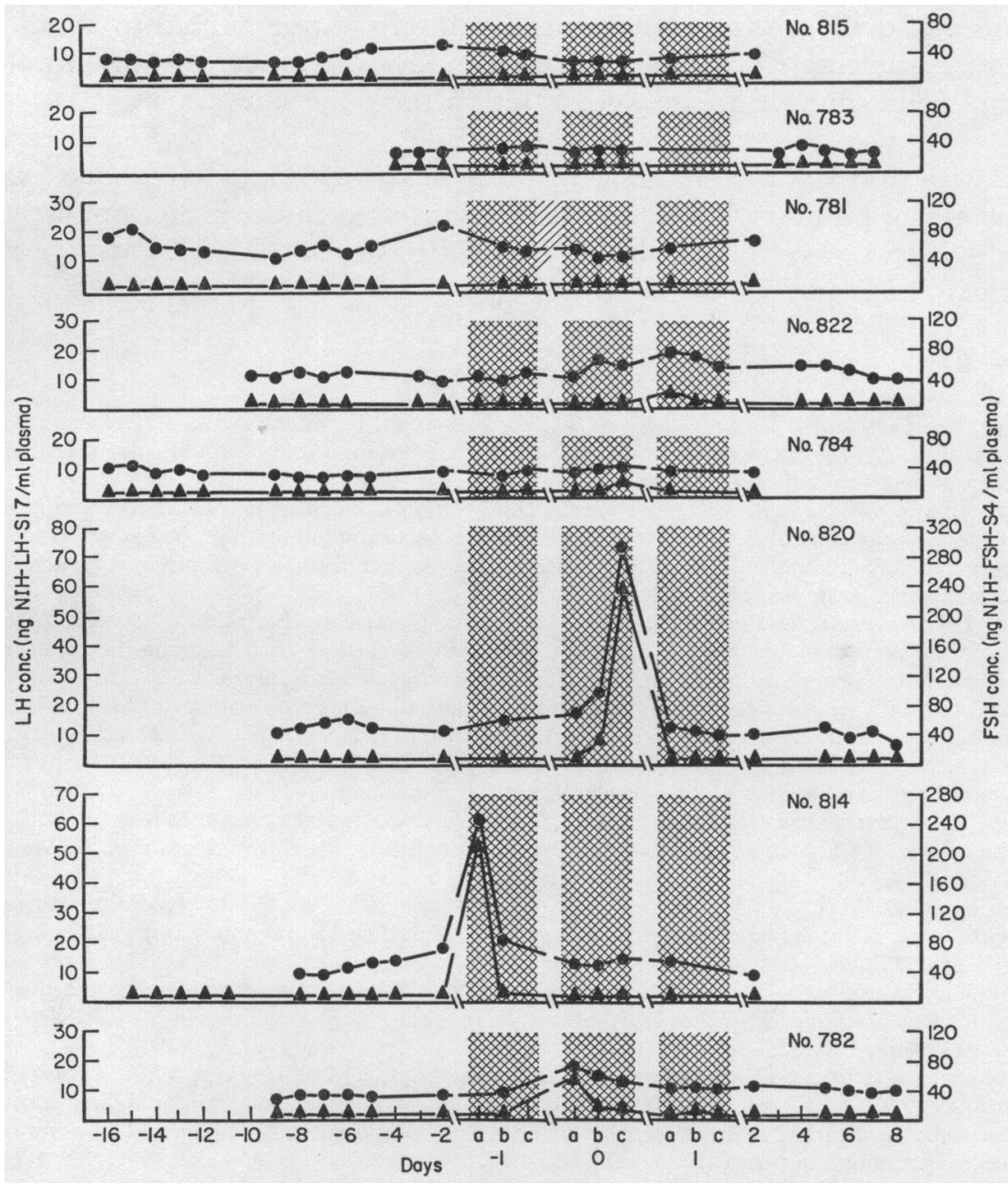

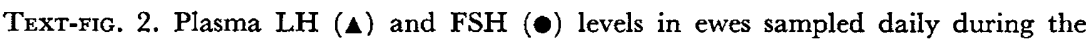
oestrous cycle. The shaded areas (Days $-1,0$ and 1 of the cycle) represent days when up to three samples were taken at approximately 09.00 hours (Sample a), 12.00 hours (Sample $b$ ) and 15.30 hours (Sample $c$ ). Day $0=$ day of oestrus.

highest. In contrast, Bjersing et al. (1972) reported no significant elevation of plasma FSH in ewes 6 and $15 \mathrm{hr}$ after the onset of oestrus, although plasma LH levels at these times were markedly raised. In addition to the preovulatory FSH surge, L'Hermite et al. (1972), Pant et al. (1973) and Salamonsen et al. (1973) found that there was a second FSH peak about $24 \mathrm{hr}$ later that was 
associated with basal LH levels. We found no evidence of this second FSH peak in our experiments, but we cannot rule out the possibility that it occurred during a period when there was a long interval between samples.

The data presented above confirm that, in the cyclic ewe, plasma progesterone values fall to very low levels on the day before oestrus, and suggest that there is a surge of both $\mathrm{LH}$ and FSH around the time of oestrus which presumably triggers ovulation. The results show that the timing of this surge relative to the onset of overt oestrus varied considerably from one animal to another. In those ewes showing elevated gonadotrophin levels, however, maximum plasma $\mathrm{LH}$ and FSH concentrations were found in the same samples.

We wish to thank the National Institute of Arthritis and Metabolic Diseases for the gift of pituitary hormone preparations used in the radioimmunoassays, and also Miss E. M. Dawson, Mr J. J. P. Hattersley and Mr H. Patel for skilled technical assistance.

\section{REFERENCES}

Bjersing, L., Hay, M.F., Kann, G., Moor, R.M., Naftolin, F., Scaramuzzi, R.J., Short, R.V. \& YouvgLaI, E.V. (1972) Changes in gonadotrophins, ovarian steroids and follicular morphology in sheep at oestrus. F. Endocr. 52, 465-479.

Challis, J.R.G., HeAP, R.B. \& Illingworth, D.V. (1971) Concentrations of oestrogen and progesterone in the plasma of non-pregnant, pregnant and lactating guinea-pigs. $\mathcal{J}$. Endocr. 51, 333-345.

Cunningham, N.F. \& Hebert, G.N. (1973) A solid-phase radioimmunoassay for ovine follicle-stimulating hormone. F. Endocr. 58, 239-249.

Goding, J.R., Catt, K.J., Brown, J.M., Kaltenbach, C.C., Cumming, I.A. \& Mole, B.J. (1969) Radioimmunoassay for ovine luteinizing hormone. Secretion of luteinizing hormone during estrus and following estrogen administration in the sheep. Endocrinology 85, 133-142.

KANN, G. (1971) Variations des concentrations plasmatique de l'hormone lutéinisante et de la prolactine au cours du cycle oestrien de la Brebis. C. r. hebd. Séanc. Acad. Sci., Paris 272, 2934-2937.

L'Hermite, M., Niswender, G.D., Reichert, L.E., JR \& Midgley, A.R., JR (1972) Serum folliclestimulating hormone in sheep as measured by radioimmunoassay. Biol. Reprod. 6, 325-332.

Lishman, A.W., Stielau, W.J., Dreosti, I.E., Botha, W.A., Stewart, A.M. \& Swart, C.E. (1974) The release of $\mathrm{LH}$ at oestrus in ewes on two planes of nutrition during lactation. F. Reprod. Fert. 41, 227-230.

Niswender, G.D., Roche, J.F., Foster, D.L. \& Midgley, A.R., JR (1968) Radioimmunoassay of serum levels of luteinizing hormone during the cycle and early pregnancy in ewes. Proc. Soc. exp. Biol. Med. 129, 901-904.

Pant, H.C., Fitzpatrick, R.J. \& Hopkinson, C. (1973) Interrelationship between plasma follicle stimulating hormone (FSH) and $17 \beta$-oestradiol in sheep during the oestrous cycle. Acta endocr., Copenh. Suppl. 177, 12.

Salamonsen, L.A., Jonas, H.A., Burger, H.G., Buckmaster, J.M., Chamley, W.A., Cumming, I.A., FindLAY, J.K. \& Goding, J.R. (1973) A heterologous radioimmunoassay for follicle-stimulating hormone: application to measurement of FSH in the ovine estrous cycle and in several other species including man. Endocrinology 93, 610-618.

Stabenfeldt, G.H., Holt, J.A. \& Ewing, L.L. (1969) Peripheral plasma progesterone levels during the ovine estrous cycle. Endocrinology 85, 11-15.

Symons, A.M. (1973) Levels of oestrogen and progesterone in the plasma of the cow during the last week of pregnancy. 7. Endocr. 56, 327-328.

Symons, A.M., Cunningham, N.F. \& SABA, N. (1974) The gonadotrophic hormone response of anoestrous and cyclic ewes to synthetic luteinizing hormone-releasing hormone. F. Reprod. Fert. 39, $11-21$.

ThorbuRn, G.D., BassetT, J.M. \& Sмiтh, I.D. (1969) Progesterone concentration in the peripheral plasma of sheep during the oestrous cycle. 7 . Endocr. 45, 459-469.

WhEATLEY, I.S. \& RADFORD, H.M. (1969) Luteinizing hormone secretion during the oestrous cycle of the ewe as determined by radioimmunoassay. F. Reprod. Fert. 19, 211-214. 